\title{
Knowledge, Attitude and Practice on Antibiotics Use and Its Resistance among Medical Students in a Tertiary Care Hospital
}

\author{
Ruchi Shrestha' \\ 'Department of Pharmacology, Kathmandu University School of Medical Sciences, Dhulikhel, Nepal.
}

\section{ABSTRACT}

Introduction: Antimicrobial resistance is an urgent and serious global health problem, demanding considerable attention from health care professionals worldwide. The unavoidable consequence of widespread use of these agents has been the reason for emergence of antibiotic resistant pathogens, leading to increase in need for new drugs. This study aims to access knowledge, attitude and practice towards antibiotics use and its resistance in undergraduate medical students.

Methods: A descriptive cross-sectional study was conducted among 228 undergraduate medical students studying in a tertiary care hospital in February, 2018. Data was collected through self administered questionnaire and was entered in Statistical Package for Social Sciences. Descriptive statistical analysis was carried out to find out knowledge, attitude and practice on antibiotics use and its resistance on medical students.

Results: The mean knowledge, attitude and practice score towards antibiotics use among students was $7.44 \pm 1.26,3.35 \pm 1.12$ and $5.06 \pm 1.45$ respectively. Out of total students, only $39(17.1 \%)$ had good knowledge and practice whereas $114(50 \%)$ had good attitude towards antibiotics use. Approximately, all 224 (98.2\%) students were aware that antibiotics are useful for bacterial infection. Fifty two (22.8\%) students said that antibiotics are safe drugs, therefore, can be used commonly.

Conclusions: Although half of the students had good attitude, majority had moderate knowledge and practice towards antibiotics use. Adequate educational training should be provided to future doctors regarding proper prescribing, dispensing and usage of antibiotics.

Keywords: antibiotics; attitude; knowledge; medical students.

\section{INTRODUCTION}

Antibiotics have not only saved patient's lives, they have also played important role in achieving major advances in therapeutics. ${ }^{1}$ However, the emergence of bacterial strains resistant to antimicrobial agents presents a growing concern worldwide and has lead to global antibiotics crisis. ${ }^{2}$
Medical students are the future doctors. To promote judicious use of antibiotics, adequate training should be provided to undergraduate medical students regarding proper prescribing, dispensing and use of antibiotics. ${ }^{3}$ Importance of these issues should be emphasized at this crucial time, because once they become qualified,

Correspondence: Dr. Ruchi Shrestha, Department of Pharmacology, Kathmandu University School of Medical Sciences, Dhulikhel, Nepal. Email: ruchistha11@gmail.com, Phone: +977. 9843410781. 
it is difficult to change their deeply rooted views and behavior. $^{4}$

This study was undertaken among first and second year undergraduate medical students to assess their Knowledge, Attitude and Practices (KAP) regarding antibiotics use and its resistance.

\section{METHODS}

This is descriptive cross-sectional study conducted in Universal College of Medical Sciences (UCMS), Bhairahawa, Nepal. Data collection was done from $6^{\text {th }}$ to $22^{\text {nd }}$ February, 2018. Ethical approval was obtained from the Institutional Review Committee of UCMS (UCMS/IRC/012/18). All MBBS and BDS students studying in first and second year were included in the study. Consent was taken from each student prior to data collection.

Semi-structured questionnaire were developed after reviewing previously published related studies with few modifications. ${ }^{6-8}$ Questionnaire was divided into 4 parts. First part included demographic profile of students, $2^{\text {nd }}$ part consisted of nine questions to assess the knowledge of students about antibiotics and its resistance, $3^{\text {rd }}$ part included five questions to access the attitude of students towards rational use of antibiotics and $4^{\text {th }}$ part consisted of eight questions which was related to practices to self medication of antibiotics. Knowledge and attitudes regarding antibiotic and its resistance were analysed using 5-point Likert scale, whose responses ranged from $1=$ strongly agree, $2=$ agree, $3=$ neither agree nor disagree, $4=$ disagree and $5=$ strongly disagree. Student's self reported practices regarding antibiotic usage was also assessed using Likert scale whose responses ranged from 'always' to 'never'. The questionnaire was distributed to first and second year MBBS and BDS students during one of their pharmacology practical classes. Each participant was allotted 20 minutes to answer the questionnaire in the form of options which he/she felt appropriate to answer.

One point was given for each correct answer whereas no deduction was done for wrong, neither agree nor disagree and sometimes responses. In knowledge questionnaire on antibiotics use, those who got score between 7-9, 4-6 and 0-3 were considered as having good, moderate and poor knowledge respectively. In attitude questionnaire, those who got score between 4-5, 2-3 and 0-1 were considered as having good, moderate and poor attitude respectively. In practice questionnaire, those who got score between 7-8, 4-6 and 0-3 were considered as having good, moderate and poor practice respectively on antibiotics use.

The collected data was coded and entered in Statistical Package for Social Sciences (SPSS) version 16. Frequency and percentage were calculated to find out the students KAP towards antibiotics use and its resistance.

\section{RESULTS}

In this study, questionnaire was distributed to all the students i.e. 290 out of which, there were 252 returns. Twenty four questionnaires were subsequently excluded because of incomplete data. The final response rate was $228(78.62 \%)$, out of which $124(54.4 \%)$ were male and 104 (45.6\%) were female. The mean age of study participants was found to be $19.83 \pm 1.43$ years.

To make the analysis easier in knowledge and attitude questionnaire, "Strongly Agree" and "Agree" was merged into "Agree", and "Strongly Disagree" and "Disagree" was merged into "Disagree". Majority 211 $(92.5 \%)$ of the students were aware of the fact that indiscriminate and injudicious use of antibiotics can lead to ineffective treatment. Antibiotics were first choice drugs for $70(30.7 \%)$ students when they had cough and sore throat. More than half $120(52.6 \%)$ students never discarded remaining, leftover antibiotics (Table 1, 2 and 3).

The mean KAP score among students in this study was $7.44 \pm 1.26,3.35 \pm 1.12$ and $5.06 \pm 1.45$ respectively. Out of total students, $39(17.1 \%)$ had good knowledge and practice whereas 114 (50\%) had good attitude towards antibiotics use (Table 4 and 5). 
Table 1. Knowledge on antibiotics use and its resistance.

\begin{tabular}{|c|c|c|c|}
\hline Questions & $\begin{array}{l}\text { Agree } \\
\text { n (\%) }\end{array}$ & $\begin{array}{l}\text { Neither agree } \\
\text { nor disagree } \\
\text { n (\%) }\end{array}$ & $\begin{array}{l}\text { Disagree } \\
\mathrm{n}(\%)\end{array}$ \\
\hline Antibiotics are useful for bacterial infection & $224(98.2)$ & $0(0)$ & $4(1.8)$ \\
\hline Antibiotics are useful for viral infection & $59(25.9)$ & $11(4.8)$ & $158(69.3)$ \\
\hline $\begin{array}{l}\text { Use of antibiotics will speed up recovery from flu and } \\
\text { cold }\end{array}$ & $105(46.1)$ & $13(5.7)$ & $110(48.2)$ \\
\hline $\begin{array}{l}\text { Antibiotics resistance means that if antibiotics are taken } \\
\text { too often, they are less likely to work in future }\end{array}$ & $190(83.3)$ & $3(1.3)$ & $35(15.4)$ \\
\hline $\begin{array}{l}\text { Antibiotics resistance is important and serious global } \\
\text { public health issue }\end{array}$ & $202(88.6)$ & $15(6.6)$ & $11(4.8)$ \\
\hline \multicolumn{4}{|l|}{ Indiscriminate and injudicious antibiotics use can lead to } \\
\hline i) Ineffective treatment & $211(92.5)$ & $5(2.2)$ & $12(5.3)$ \\
\hline ii) Increased adverse effects & $212(93)$ & $7(3.1)$ & $9(3.9)$ \\
\hline iii) Increased cost burden to the patient & $203(89.1)$ & $11(4.8)$ & $14(6.1)$ \\
\hline $\begin{array}{l}\text { Antibiotics can cause secondary infections after killing } \\
\text { good bacteria present in the body }\end{array}$ & $168(73.7)$ & $24(10.5)$ & $36(15.8)$ \\
\hline
\end{tabular}

Table 2. Attitude towards antibiotics use.

\section{Questions}

Antibiotics are safe drugs, hence they can be used commonly

Skipping one or two doses does not contribute to development of antibiotics resistance

Adverse effects of antibiotics are reduced by using more than one antibiotic at a time

Injudicious use of antibiotics shortens the duration of illness

When you have a cough and sore throat, antibiotics are the first drug of choice for early treatment and to prevent emergence of resistant strains

\begin{tabular}{|lll|}
\hline $\begin{array}{l}\text { Agree } \\
\mathbf{n}(\%)\end{array}$ & $\begin{array}{l}\text { Neither agree nor } \\
\text { disagree } \mathbf{n}(\%)\end{array}$ & $\begin{array}{l}\text { Disagree } \\
\mathbf{n}(\%)\end{array}$ \\
$52(22.8)$ & $30(13.2)$ & $146(64)$ \\
$59(25.8)$ & $12(5.3)$ & $157(68.9)$ \\
$66(29))$ & $29(12.7)$ & $133(58.3)$ \\
$30(13.2)$ & $18(7.9)$ & $180(78.9)$ \\
$70(30.7)$ & $15(6.6)$ & $143(62.7)$ \\
\hline
\end{tabular}

\begin{tabular}{|c|c|c|c|}
\hline Questions & $\begin{array}{l}\text { Always } \\
\text { n (\%) }\end{array}$ & $\begin{array}{l}\text { Sometimes } \\
\text { n (\%) }\end{array}$ & $\begin{array}{l}\text { Never } \\
\text { n (\%) }\end{array}$ \\
\hline \multicolumn{4}{|l|}{$\begin{array}{l}\text { The doctor prescribes a course of antibiotic for you. After } \\
\text { taking } 2-3 \text { doses you start feeling better }\end{array}$} \\
\hline i) You stop taking the further treatment? & $5(2.2)$ & $52(22.8)$ & $171(75)$ \\
\hline $\begin{array}{l}\text { ii) Do you save the remaining antibiotics for the next time you } \\
\text { get sick? }\end{array}$ & $13(5.7)$ & $53(23.2)$ & $162(71.1)$ \\
\hline iii) Do you discard the remaining, leftover medication? & $28(12.3)$ & $80(35.1)$ & $120(52.6)$ \\
\hline $\begin{array}{l}\text { iv) Do you give the leftover antibiotics to your friend/family } \\
\text { members if they get sick? }\end{array}$ & $13(5.7)$ & $85(37.3)$ & $130(57)$ \\
\hline v) Do you complete the full course of treatment? & $180(78.9)$ & $41(18)$ & $7(3.1)$ \\
\hline Do you consult doctor before starting an antibiotic? & $190(83.3)$ & $37(16.2)$ & $1(0.4)$ \\
\hline Do you check expiry date of the antibiotic before using it? & $223(97.8)$ & $4(1.8)$ & $1(0.4)$ \\
\hline $\begin{array}{l}\text { Do you prefer to take antibiotic when you have cough and } \\
\text { sore throat? }\end{array}$ & $15(6.6)$ & $147(64.5)$ & $66(28.9)$ \\
\hline
\end{tabular}


Shrestha. Knowledge, Attitude and Practice on Antibiotics Use and its Resistance among Medical Students

\begin{tabular}{|llll|}
\hline Table 4. KAP score. & & \\
\hline & Minimum & Maximum & Mean score \\
& score & score & \\
Knowledge & 1 & 9 & $7.44 \pm 1.26$ \\
Attitude & 1 & 5 & $3.35 \pm 1.12$ \\
Practice & 1 & 8 & $5.06 \pm 1.45$ \\
\hline
\end{tabular}

\begin{tabular}{|llll|}
\hline \multicolumn{4}{|l|}{ Table 5. KAP level of students. } \\
\hline & Good & Moderate & Poor \\
& $\mathbf{n}(\%)$ & $\mathbf{n}(\%)$ & $\mathbf{n}(\%)$ \\
Knowledge & $39(17.1)$ & $153(67.1)$ & $36(15.8)$ \\
Attitude & $114(50)$ & $101(44.3)$ & $13(5.7)$ \\
Practice & $39(17.1)$ & $151(66.2)$ & $38(16.7)$ \\
\hline
\end{tabular}

\section{DISCUSSION}

Antibiotics are the most frequently prescribed drugs, but often misused. ${ }^{9}$ Antibiotic resistance is increasing all over the world and presents a growing concern worldwide. ${ }^{10}$ The clinical effectiveness of antibiotics depends on their correct use by patients, physicians and retailers. ${ }^{11}$ Prescriber's decisions may be influenced by factors such as fear of losing their patients, lack of information on rational use of antibiotics, excessive and unnecessary antibiotic prescribing, incorrect dosage or route of administration, antibiotic prescribing for non-bacterial infections, patient demands and self prescribing. ${ }^{12-15}$ Patient factors relating to incorrect antibiotic use include self-medication, sharing medication, not taking full course of treatment and keeping part of the course for next time. ${ }^{16}$ Poor infection control practices and increasing use of antibiotics in agriculture, farming and aquaculture has also led to global concern for antibiotics resistance..$^{1,17}$

Majority $88.6 \%$ of the students in this study were well aware of the global problem of antimicrobial resistance. The finding was similar to the study done in Congo in medical students and practicing medical doctors in which $85.4 \%$ participants said antibiotics resistance is important global problem. ${ }^{18}$ Approximately $98 \%$ students in our study were aware of the fact that antibiotics are useful for bacterial infection which was similar to the study done in Italy which suggested 95.2\% medical students were aware that antibiotics are useful for treatment of bacterial infections. ${ }^{6}$ However, in this study, $25.9 \%$ students agreed that antibiotics are also useful for viral infections and $46.1 \%$ said use of antibiotics causes speed recovery from cold and flu. The findings were contrast to the study done in $\operatorname{Iran}^{19}$ which reported $100 \%$ of the medical students believed that antibiotics do not cure viral illnesses and in China? in which $72.6 \%$ students said use of antibiotics speed up recovery from flu and cold. Such wrong beliefs may lead to inappropriate increased rates of antibiotic consumption, which can result in increase in bacterial resistance. ${ }^{20}$

In response to survey question, "antibiotics are safe drugs; hence they can be used commonly", 64\% disagreed. The response was similar to Indian study in which $78.4 \%$ students disagreed to the same question. ${ }^{8}$ Approximately $30 \%$ students said that antibiotics are the first choice drugs when they get cough and sore throat whereas $52.32 \%$ gave the same response in a study done in India. ${ }^{21}$

In response to self medication questions related to antibiotics, $83.3 \%$ students said they always consulted doctors before taking antibiotics, which was similar to the study carried out in Italy which reported $81.38 \%$ medical students consulted doctors before taking antibiotics. ${ }^{6}$ However, study done in general public revealed that approximately one-third had got antibiotics directly from pharmacy without physician consultation as shown by the study done in Italy $(32.7 \%),{ }^{22}$ and Jordan $(30.5 \%){ }^{23}$ Majority $78.9 \%$ of the students completed the full course of antibiotics which was similar to the study in which $74.2 \%^{8}$ and $94.18 \%^{20}$ medical students completed the course.

Existing gaps are present in the knowledge, attitude and practice of antibiotics use in medical and non medical students as shown by various studies. Overall knowledge, attitude and perception of medical students were better when compared to non medical students whereas behaviour towards antibiotics use was poor in medical students when compared to non medical students as shown by the study in China. ${ }^{7}$ In study done in Libya where rate of self medication was compared, $43 \%$ of the medical students were self medicated as compared to $31 \%$ of non medical students. ${ }^{24}$ This could be due to their self confidence and knowledge gained from medical study. ${ }^{25}$

The present study had several limitations. Opinions of students of single teaching hospital were taken. So, the results cannot generalize the whole population of medical students. In order to know the exact scenario, perception of all the medical students in the national level should be included. Secondly, all the answers were not given honestly as some of the students discussed among them while filling the questionnaire. Finally, the number and way of questions may not reflect the real KAP of the students.

\section{CONCLUSIONS}

This study revealed an important insight regarding the 
KAP regarding antibiotics use and its resistance among medical students. Although half of the students had good attitude, majority had moderate knowledge and practice towards antibiotics use. Medical students are future doctors who are going to practice in medical field, so if they have clear concept about antibiotics like when to use and when not, antibiotics resistance can be reduced to greater extent. The medical education strategies should aim to provide adequate training on the rational use of antibiotics and not only to increase the knowledge but also to change the behaviour and practices among medical students regarding antibiotics use. Effective undergraduate curriculum should be developed to enhance future doctor's knowledge, attitude and practices for usage of antibiotics.

\section{ACKNOWLEDGEMENTS}

I acknowledge all the participants of UCMS. I would also like to thank Dr. Niraj Pandey and Dr. Laxmi Shrestha for their co-operation during data collection.

\section{Conflict of Interest: None.}

\section{REFERENCES}

1. Gould IM, Bal AM. New antibiotic agents in the pipeline and how they can help overcome microbial resistance. Virulence. 2013;4(2):185-91. [PubMed | Full Text | DOI]

2. Spellberg B, Guidos R, Gilbert D, Bradley J, Boucher HW, Scheld WM, et al. The epidemic of antibiotic-resistant infections: a call to action for the medical community from the infectious diseases society of America. Clin Infect Dis. 2008 jan15;46(2):155-64. [PubMed | Full Text | DOI]

3. Steinberg I. Clinical choices of antibiotics: judging judicious use. Am J Manag Care. 2000;6(23 Suppl):S1178-88. [PubMed | Full Text]

4. Simpson SA, Wood F, Butler CC. General practitioners perceptions of antimicrobial resistance: a qualitative study. J Antimicrob Chemother. 2007;59(2):292-6. [PubMed | Full] Text | DOI]

5. Wasserman S, Potgieter S, Shoul E, Constant D, Stewart A, Mendelson M, et al. South African medical students' perceptions and knowledge about antibiotic resistance and appropriate prescribing: are we providing adequate training to future prescribers? S Afr Med J. 2017;107(5):405-10. [PubMed | Full Text]

6. Scaioli G, Gualano MR, Gili R, Masucci S, Bert F, Siliquini R. Antibiotic use: a cross-sectional survey assessing the knowledge, attitudes and practices amongst students of a school of medicine in Italy. PLoS One. 2015;10(4):e0122476. [PubMed | Full Text | DOI]

7. Huang Y, Gu J, Zhang M, Ren Z, Yang W, Chen Y, et al. Knowledge, attitude and practice of antibiotics: a questionnaire study among 2500 Chinese students. BMC Med Educ. 2013;13:163. [PubMed | Full Text | DOI]

8. Afzal Khan A, Banu G, Reshma K. Antibiotic resistance and usage-a survey on the knowledge, attitude, perceptions and practices among the medical students of a southern Indian teaching hospital. J Clin Diag Res. 2013;7(8):1613-6. [PubMed | Full Text | DOI]

9. Chambers HF. General principles of antimicrobial therapy. Petri WA. Penicillins, cephalosporins, and other $\beta$-Lactam Antibiotics. Brunton LL, Lazo JS, Parker KL, editors. Goodman and Gillman's Pharmacological basis of Therapeutics. 11th ed. New York: McGraw-Hill; 2006: 1095-110 p. [Full Text]

10. Baktygul K, Marat B, Ashirali Z, Harun-Or-Rashid M, Sakamoto J. An assessment of antibiotics prescribed at the secondary health-care level in the Kyrgyz Republic. Nagoya J Med Sci. 2011;73(3-4):157-68. [PubMed | Full Text]

11. Radyowijati A, Haak H. Determinants of antimicrobial use in the developing world. [place unknown]: Johns Hopkins University, Office of Design and Publications; 2002. 39 p. [Full Text]

12. Harbarth S, Albrich W, Brun-Buisson C. Outpatient antibiotic use and prevalence of antibiotic-resistant pneumococci in France and Germany: a sociocultural perspective. Emerg Infect Dis. 2002;8(12):1460-7. [PubMed | Full Text | DOI]

13. Vazquez-Lago JM, Lopez-Vazquez P, López-Durán A, Taracido-Trunk M, Figueiras A. Attitudes of primary care physicians to the prescribing of antibiotics and antimicrobial resistance: a qualitative study from Spain. Fam Pract. 2011;29(3):352-60. [PubMed | Full Text | DOI]

14. Ali MH, Kalima P, Maxwell SRJ. Failure to implement hospital antimicrobial prescribing guidelines: a comparison of two UK academic centres. J Antimicrob Chemother. 2006;57(5):959-62. [Full Text | DOI]

15. Cadieux G, Tamblyn R, Dauphinee D, Libman M. Predictors of inappropriate antibiotic prescribing among primary care physicians. Can Med Assoc J. 2007;177(8):877-83. [PubMed | DOI]

16. Grigoryan L, Burgerhof JGM, Haaijer-Ruskamp FM, Degener JE, Deschepper R, Monnet DL, et al. Is self-medication with antibiotics in Europe driven by prescribed use? J Antimicrob Chemother. 2007;59(1):152-6. [PubMed | Full Text | DOI]

17. Hollis A, Ahmed Z. Preserving antibiotics, rationally. N Engl J Med. 2013;369(26):2474-6. [PubMed | Full Text | DOI]

18. Thriemer K, Katuala Y, Batoko B, Alworonga JP, Devlieger $\mathrm{H}$, Van Geet $\mathrm{C}$, et al. Antibiotic prescribing in DR Congo: a knowledge, attitude and practice survey among medical 
doctors and students. PloS One. 2013;8(2):e55495. [PubMed | Full Text | DOI]

19. Jorak A, Keihanian F, Saeidinia A, Heidarzadeh A, Saeidinia F. A cross sectional study on knowledge, attitude and practice of medical students toward antibiotic resistance and its prescription, Iran. Iran J Public Health. 2014;8(17):675-81. [Full Text]

20. Zafar SN, Syed R, Waqar S, Zubairi AJ, Vaqar T, Shaikh M, et al. Self-medication amongst university students of Karachi: prevalence, knowledge and attitudes. J Pak Med Assoc. 2008;58(4):214-7. [PubMed | Full Text]

21. Mahajan M, Dudhgaonkar S, Deshmukh S. A Questionnaire based survey on the knowledge, attitude and practises about antimicrobial resistance and usage among the second year MBBS students of a teaching tertiary care hospital in central India. International Journal of Pharmacological Research.

$$
\text { 2014;4(4):175-9. [Full Text] }
$$

22. Napolitano F, Izzo MT, Di Giuseppe G, Angelillo IF. Public knowledge, attitudes, and experience regarding the use of antibiotics in Italy. PloS One. 2013;8(12):e84177. [PubMed | Full Text | DOI]

23. Shehadeh M, Suaifan G, Darwish RM, Wazaify M, Zaru L, Alja'fari S. Knowledge, attitudes and behavior regarding antibiotics use and misuse among adults in the community of Jordan. A pilot study. Saudi Pharm J. 2012;20(2):125-33. [PubMed | Full Text | DOI]

24. Ghaieth MF, Elhag SR, Hussien ME, Konozy EH. Antibiotics self-medication among medical and nonmedical students at two prominent Universities in Benghazi city, Libya. J Pharm Bioallied Sci. 2015;7(2):109-15. [PubMed | Full Text | DOI]

25. Al-Hussaini M, Mustafa S, Ali S. Self-medication among undergraduate medical students in Kuwait with reference to the role of the pharmacist. J Res Pharm Pract. 2014;3(1):23-7. [PubMed | Full Text | DOI]

(c) The Author(s) 2018.

This work is licensed under a Creative Commons Attribution 4.0 International License. The images or other third party material in this article are included in the article's Creative Commons license, unless indicated otherwise in the credit line; if the material is not included under the Creative Commons license, users will need to obtain permission from the license holder to reproduce the material. To view a copy of this license, visit http://creativecommons.org/licenses/by/4.0/ 